\title{
STUDI EVALUASI KINERJA GURU DALAM PENERAPAN PJBL INSTALASI MOTOR LISTRIK XI TIPTL SMKN 3 SINGARAJA
}

\author{
I. W. W. Adnyana ${ }^{1}$, N.Santiyadnya ${ }^{2}$, K. U. Ariawan ${ }^{3}$ \\ 1,2Prodi Pendidikan Teknik Elektro, Universitas Pendidikan Teknik Elektro, Singaraja \\ ${ }^{3}$ Prodi Teknik Elektronika, Universitas Pendidikan Ganesha, Singaraja \\ e-mail: luminos94@gmail.com, santiyadnya@undiksha.ac.id, udyariawan@undiksha.ac.id
}

\begin{abstract}
Abstrak
Penelitian ini bertujuan mendeskripsikan kinerja guru dalam penerapan model pembelajaran project based learning pada mata pelajaran instalasi motor listrik kelas XI TIPTL SMK Negeri 3 Singaraja yang berkaitan dengan penerapan model project based learning pada tahap perencanaan, tahap pelaksanaan, dan tahap evaluasi pembelajaran. Metode penelitian yang digunakan, yaitu kualitatif deskriptif. Subjek penelitian ini adalah dua orang guru mata pelajaran instalasi motor listrik serta 6 siswa kelas XI TIPTL di SMK Negeri 3 Singaraja. Teknik pengumpulan data yang digunakan, yaitu wawancara, observasi partisipasi pasif dan studi dokumentasi. Berdasarkan analisis data, didapat hasil antara lain. 1) perencanaan pembelajaran yang dilakukan kurang sesuai dengan aspek kinerja guru dalam penerapan model pembelajaran project based learning, karena beberapa item belum terlaksana. 2) pelaksanaan pembelajaran yang dilakukan guru terbagi menjadi tiga tahap meliputi pendahuluan, kegiatan inti, dan penutup, dalam penerapan masih belum optimal penerapannya terhadap RPP, Permendikbud dan langkah-langkah project based learning. 3) evaluasi pembelajaran dilakukan guru dengan tiga aspek meliputi aspek pengetahuan, sikap, dan keterampilan, namun belum optimal, dikarenakan beberapa item belum dilaksanakan.
\end{abstract}

Kata kunci: Kinerja guru, Project based learning, Instalasi motor listrik

\begin{abstract}
This study aims to describe the performance of teachers in the application of the model learning project based learning on the subjects of class XI installation of electric motors TIPTL SMK Negeri 3 Singaraja relating to the implementation of models project based learning at the planning, implementation, and evaluation stages of learning. The method used, which is qualitative descriptive. The subjects were two teachers of subjects as well as the installation of an electric motor 6 TIPTL grade students at SMK Negeri 3 Singaraja. Data collection techniques used, namely interviews, observation and documentation study passive participation. Based on data analysis, the result among others. 1) planning of learning is done not in accordance with aspects of the performance of teachers in the implementation of project based learning model of learning, because some items have not been implemented. 2) implementation of learning that teachers are divided into three stages include the introduction, core activities, and cover, the application is still not optimal implementation of the RPP, Permendikbud and measures of project based learning. 3) evaluation of learning by teacher with three aspects include aspects of knowledge, attitudes, and skills, but not optimal, because some items have not been implemented.
\end{abstract}

Keywords: Teacher performance, Project based learning, Installation of electric motors

\section{Pendahuluan}

Model pembelajaran project based learning merupakan model pembelajaran yang berbasis proyek atau pembelajaran yang yang menggunakan sistem praktikum. Menurut Gaer (dalam I Gusti Ayu Tri Agustiana dkk, 2013:278) pembelajaran berbasis proyek memiliki potensi yang amat besar untuk membuat pengalaman belajar yang lebih menarik dan bermakna bagi pebelajar usia dewasa untuk membangun keterampilan kerja. 
Hal ini sejalan dengan tujuan khusus pendidikan menengah kejuruan, yaitu (a) menyiapkan peserta didik agar menjadi manusia produktif, mampu bekerja mandiri, mengisi lowongan pekerjaan yang ada sebagai tenaga kerja tingkat menengah sesuai dengan kompetensi dalam program keahlian yang dipilihnya; (b) menyiapkan peserta didik agar mampu memilih karir, ulet dan gigih dalam berkompetensi, beradaptasi di lingkungan kerja dan mengembangkan sikap profesional dalam bidang keahlian yang diminatinya; (c) membekali peserta didik dengan ilmu pengetahuan, teknologi dan seni agar mampu mengembangkan diri di kemudian hari baik secara mandiri maupun melalui jenjang pendidikan yang lebih tinggi; dan (d) membekali peserta didik dengan kompetensikompetensi yang sesuai dengan program keahlian yang dipilih (Undang-Undang Nomor 20 Tahun 2003).

Model pembelajaran project based learning memang cocok diterapkan pada pembelajaran instalasi motor listrik mengingat pembelajaran tersebut banyak melakukan praktikum-praktikum didalam kelas. Pemilihan model pembelajaran project based learning yang diterapkan di dalam kelas akan optimal jika penerapannya dilakukan dengan sungguh-sungguh oleh guru. Selain penerapan yang sungguh-sungguh oleh guru pengajar, keberhasilan penerapan juga tergantung dari pada kinerja di dalam penerapannya oleh guru pengajar.

Kinerja seorang guru dapat dinilai dari bagaimana cara mengajar dari mulai masuk kelas sampai dengan jam pelajaran selesai. Pengawasan terhadap siswa yang melakukan praktikum sering menjadi hal yang dianggap remeh sehingga penerapan model pembelajaran menjadi kurang efisien. Dengan kinerja yang baik diharapkan penerapan model pembelajaran menjadi efisien dan siswa menjadi lebih memahami makna yang disampaikan oleh guru pengajar sehingga pembelajaran menjadi lebih efisien, tepat sasaran, dan tujuan pembelajaran dapat tercapai.

Berdasarkan uraian diatas maka penerapan suatu model pembelajaran sangat penting dimana dalam kasus ini penerapan model pembelajaran project based learning (PBL) yang disertai kinerja yang baik untuk memajukan pemahaman siswa. Hal tersebut mendorong peneliti untuk mengungkapkan bagaimana kinerja guru dalam penerapan model pembelajaran project based learning pada mata pelajaran Instalasi Motor Listrik di SMK Negeri 3 Singaraja dan bagaimana penerapan model pembelajaran project based learning pada mata pelajaran Instalasi Motor Listrik di SMK Negeri 3 Singaraja.

Rencana pemecahan masalah melalui evaluasi yang bertujuan untuk. mendeskripsikan kinerja guru dalam penerapan model pembelajaran project based learning pada tahap perencanaan pembelajaran Instalasi Motor Listrik di kelas XI TIPTL SMK Negeri 3 Singaraja, mendeskripsikan kinerja guru dalam penerapan model pembelajaran project based learning pada tahap pelaksanaan pembelajaran Instalasi Motor Listrik di kelas XI TIPTL SMK Negeri 3 Singaraja, dan mendeskripsikan kinerja guru dalam penerapan model pembelajaran project based learning pada tahap evaluasi pembelajaran Instalasi Motor Listrik di kelas XI TIPTL SMK Negeri 3 Singaraja.

Suchman (dalam Suharsimi Arikunto, 2009:1) memandang evaluasi sebagai sebuah proses menentukan hasil yang telah dicapai beberapa kegiatan yang direncanakan untuk mendukung tercapai tujuan. Definisi lain dikemukakan oleh Worthen dan Sanders (dalam Suharsimi Arikunto, 2009:1). Dua ahli tersebut mengatakan bahwa evaluasi adalah kegiatan mencari sesuatu yang berharga tentang sesuatu; dalam mencari sesuatu tersebut, juga termasuk mencari informasi yang bermanfaat dalam menilai keberadaan suatu program

,produksi, prosedur, serta alternatif strategi yang diajukan untuk mencapai tujuan yang sudah ditentukan. Seorang ahli yang sangat terkenal dalam evaluasi program bernama Stufflebea (dalam Suharsimi Arikunto, 2009:2) mengatakan bahwa evaluasi merupakan proses penggambaran, pencarian, dan pemberian informasi yang sangat bermanfaat bagi pengambil keputusan dalam menentukan alternatif keputusan.

Dari beberapa pendapat pendapat di atas dapat di simpulkan bahwa evaluasi adalah kegiatan untuk mengumpulkan informasi tentang bekerjanya sesuatu, yang selanjutnya informasi tersebut digunakan untuk menentukan alternatif yang tepat dalam mengambil sebuah keputusan. (Suharsimi Arikunto, 2009:2). Pembelajaran berbasis proyek memiliki potensi yang amat besar untuk membuat pengalaman belajar yang lebih menarik dan bermakna bagi pebelajar usia dewasa untuk membangun keterampilan kerja menurut Gaer (dalam I Gusti Ayu Tri Agustiana dkk, 2013:288). Di 
dalam PBL, pebelajar menjadi terdorong lebih aktif di dalam belajar mereka,instruktur atau dalam hal ini guru pengajar berposisi di belakang dan pebelajar berinisiatif, instruktur memberi kemudahan dan mengevaluasi proyek baik berkemaknaannya maupun penerapannya untuk kehidupan mereka sehari-hari. Produk yang dibuat pebelajar selama proyek memberikan memberikan hasil yang secara otentik dapat diukur oleh guru atau instruktur di dalam pembelajarannya. Oleh karena itu, di dalam pembelajaaran berbasis proyek, guru atau instruktur tidak lebih aktif dan melatih secara langsung, akan tetapi instruktur menjadi pendamping, fasilitator, dan memahami pikiran pebelajar.

Wena (dalam Sutirman, 2013:46) membagi tahap pembelajaran praktik kejuruan berbasis proyek menjadi tiga tahap, yaitu tahap perencanaan, tahap pelaksanaan, dan tahap evaluasi. Tahap perencanaan pembelajaran meliputi: kegiatan merumuskan tujuan proyek; menganalisis karakteristik siswa; merumuskan strategi pembelajaran; membuat jobsheet; merancang kebutuhan sumber belajar; dan merancang alat evaluasi. Tahap pelaksanaan mencangkup aktivitas mempersiapkan sumber belajara yang diperlukan; menjelaskan tugas proyek; mengelompokkan siswa sesuai dengan tugas dan mengerjakan proyek. Tahap evaluasi dilakukan untuk mengetahui ketercapaian tujuan pembelajaran oleh siswa. Hasil evaluasi menjadi bahan masukan bagi siswa dan bagi guru untuk merancang pembelajaran selanjutnya. Menurut Whitmore (dalam Hamzah, 2012:59) secara sederhana mengemukakan, kinerja adalah pelaksanaan fungsifungsi yang dituntut dari seseorang. Pengertian yang menurut whitmore merupakan pengertian yang menuntut kebutuhan paling minim untuk berhasil. Sedangkan menurut Wibowo,(2012:4) kinerja adalah merupakan implementasi dari rencana yang telah disusun tersebut. Implementasi kinerja dilakukan oleh sumber daya manusia yang memiliki kemampuan, kompetensi, motivasi dan kepentingan. Pandangan lain dikemukakan King (dalam, Hamzah B dkk, 2012:61) yang menjelaskan kinerja adalah aktivitas seseorang dalam melaksanakan tugas pokok yang dibebankan kepadanya. Untuk melihat hakikat kinerja guru, terlebih dikemukakan pandangan para ahli tentang apa sebenarnya kinerja itu. Menurut pandangan Patricia King (dalam, Hamzah, 2012:64), kinerja adalah aktivitas seseorang dalam

melaksanakan tugas pokok yang dibebankan kepadanya.

Sedangkan menurut McDaniel, yang mengemukakan kinerja adalah interaksi antara kemampuan seseorang dengan motivasinya. Berdasarkan dengan pandangan ini, ditegaskan bahwa kinerja merupakan penjumlahan antara kemampuan dan motivasi kerja yang dimiliki seseorang. Dalam kaitanya dengan kinerja guru, kinerja mereka dapat terefleksi dalam tugasnya sebagai seorang pengajar dan sebagai seorang pelaksana administrator kegiatan mengajarnya. Dengan kata lain, kinerja guru dapat terlihat pada kegiatan merencanakan, melaksanakan, dan menilai proses belajar mengajar yang itensitasnya dilandasi etos kerja dan disiplin profesional guru (Hamzah, 2012:65).

\section{Metode}

Dalam penelitian ini penulis menggunakan pendekatan kualitatif dengan menggunakan model evaluasi. Adapun model evaluasi yang digunakan adalah Discrepancy Model, yaitu Model yang menekankan pada pandangan adanya kesenjangan di dalam pelaksanaan program. Evaluasi program yang dilakukan oleh evaluator mengukur besarnya kesenjangan yang ada di setiap komponen. Model ini dipilih dikarenakan penelitian ini bertujuan untuk mendeskripsikan kesesuain kinerja dalam penerapan project based learning tahap perencanana, pelaksanaan, dan evaluasi.

Jenis penelitian yang digunakan dalam penelitian ini, yaitu deskriptif dimana dalam penelitian ini peneliti berusaha mediskripsikan gejala atau peristiwa yang terjadi di lapangan. Dalam hal ini peristiwa yang diteliti, yaitu berkenaan dengan kinerja guru dalam penerapan model pembelajaran project based learning pada mata pelajaran Instalasi Motor Listrik kelas XI TIPTL SMK Negeri 3 Singaraja dilihat dari segi perencanaan, pelaksanaan dan evaluasi.

Aspek kinerja guru dalam model pembelajaran project based learning adalah sebagai berikut. 1) aspek perencanaan, yaitu RPP, penyiapan media dan sumber belajar, perangkat penilaian pembelajaran, scenario pembelajaran, merumuskan tujuan proyek, merumuskan strategi pembelajaran, dan jobsheet, 2) aspek pelaksanaan, yaitu melakukan kegiatan pendahuluan, kegiatan inti, kegiatan penutup, orientasi, desain, pelaksanaan, dan evaluasi, 3) Aspek evaluasi, 
yaitu tes tertulis / tes lisan, penugasan, observasi/ pengamatan sikap, penilaian diri, penilaian antar teman, penilaian unjuk kerja / penilaian praktik / kinerja, penilaian fortofolio.

Adapun pelaksanaan penelitian kualitatif ini bertempat di SMK Negeri 3 Singaraja yang merupakan sekolah teknik di Singaraja yang beralamat di Jalan Gempol Desa Banyuning, Kecamatan Buleleng Kabupaten Buleleng. Penelitian ini dilaksanakan pada bidang keahlian kompetensi kelistrikan atau jurusan Teknik Instalasi Pemanfaatan Tenaga Listrik ( TIPTL ) yang dimana pembelajaran disana khususnya kelas Listrik atau TIPTL pada mata pelajaran Instalasi Motor Listrik menerapkan model pembelajaran project based learning yang merupakan objek yang akan diteliti. Selain itu SMK Negeri 3 Singaraja ini dipilih sebagai tempat penelitian karena tempat penelitian berada di daerah kota singaraja sehingga memudahkan peneliti untuk menjangkau tempat penelitian. Oleh karena itu peneliti ingin meneliti mengenai kinerja guru dalam penerapan model pembelajaran project based learning pada mata pelajaran Instalasi Motor Listrik pada kelas XI TIPTL SMK Negeri 3 Singaraja.

Penelitian ini melibatkan 2 guru yang mengajar mata pelajaran Instalasi Motor Listrik di kelas $\mathrm{XI}$. Data yang ingin peneliti cari dari guru terkait adalah data tentang kesiapan guru dalam proses pembelajaran baik dari perencanaan, pelaksanaan, dan evaluasi yang dilakukan pada saat pelaksanaan proses pembelajaran Instalasi Motor Listrik. Cara mencari data dan informasi dari guru, dengan menggunakan metode observasi, metode wawancara, dan dokumentasi.

Penelitian ini juga melibatkan siswa kelas XI TIPTL 6 orang yang mendapatkan Instalasi Motor Listrik atau siswa yang terlibat dalam proses pembelajaran Instalasi Motor Listrik. Data yang ingin di cari dari siswa adalah data tentang kesiapan siswa dalam mengikuti pelaksanaan proses pembelajaran di kelas dan minat siswa dalam mengikuti pembelajaran. Cara untuk mencari data dari siswa yang peneliti lakukan dengan metode observasi, dan metode wawancara.

Data penelitian diperoleh berdasarkan fakta-fakta yang digunakan sebagai acuan dalam menganalisis. Materi yang akan dianalisis dalam penelitian ini, yaitu (1) data transkrip hasil observasi berupa pelaksanaan pembelajaran dikelas; (2) data transkrip hasil wawancara dengan guru berupa alasan-alasan yang melatar belakangi penerapan model pembelajaran yang dilakukan, bagaimana proses penyusunan perencanaan, persiapan dalam melaksanakan pembelajaran,bagaimana kinerja penerapannya serta bentuk evaluasi yang akan diterapkan.(3) data transkrip hasil wawancara dengan siswa data dan beberapa dokumen pendukung sesuai dengan fokus penelitian.

Oleh karena jenis data dalam penelitian kualitatif ini berupa deskripsi mengenai kinerja guru dalam penerapan model pembelajaran project based learning pada mata pelajaran Instalasi Motor Listrik kelas XI TIPTL , maka adapun teknik yang digunakan adalah dengan melakukan observasi/ pengamatan, wawancara (interview) dan dokumentasi.

Pedoman Observasi digunakan untuk menggali informasi melalui pengamatan secara langsung terhadap objek yang diteliti mengenai kinerja guru dalam penerapan model pembelajatan project based learning. Pedoman wawancara digunakan untuk menggali informasi lebih mendalam mengenai kinerja guru dalam penerapan model pembelajatan project based learning. Wawancara dapat dilakukan dengan langsung kepada guru yang bersangkutan maupun dengan siswa. Dokumentasi digunakan untuk memperoleh informasi tentang kualitas kinerja guru dalam penerapan model pembelajaran project based learning yang diterapkan didalamnya.

Kegiatan analisis dalam penelitian ini dilakukan secara induktif. Analisis secara induktif dilakukan untuk menemukan simpulan akhir terhadap data yang dikumpulkan sedikit demi sedikit dari lokasi penelitian. Terdapat tiga tahapan analisis data yang dilakukan dalam penelitian kualitatif ,yaitu (1) tahap reduksi data (data reduction), (2) tahap paparan data (data display), dan (3) tahap penarikan simpulan dan verifikasi data (conclusion drawing and verification ) seperti yang terlihat pada diagram berikut 


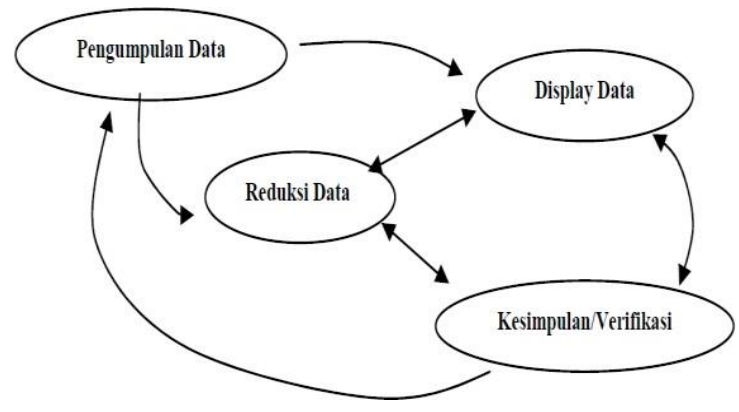

Gambar 1. Komponen dalam Analisis Data (Interactive Model)

\section{Hasil dan Pembahasan}

Hasil penelitian yang disajikan dalam penelitian ini menyangkut tiga hal pokok, yaitu 1) gambaran umum tempat penelitian; 2) gambaran umum model pembelajaran project based learning di SMK yang diteliti; 3) temuan penelitian yang meliputi: a) perencanaan model pembelajaran project based learning berbasis kinerja; b) pelaksanaan model pembelajaran project based learning berbasis kinerja; c) evaluasi model pembelajaran project based learning berbasis kinerja.

Gambaran umum tempat penelitian, yaitu Sekolah Menengah Kejuruan Negeri 3 Singaraja beralamat di jalan Gempol, desa Banyuning, Singaraja, Buleleng-Bali. SMK Negeri 3 Singaraja merupakan salah satu sekolah teknik yang ada di Singaraja dengan jurusan yang banyak dan lengkap kurang lebih 10 kompetensi keahlian. Termasuk Kompetensi keahlian TIPTL yang di dalamnya terdapat mata pelajaran Instalasi Motor Listrik dengan model pembelajaran yang dipakai adalah project based learning.

Gambaran umum model project based learning kelas XI mata pelajaran instalasi motor listrik, yaitu model pembelajaran project based learning diterapkan oleh guru A dan guru B di kelas XI Teknik Instalasi Pemanfaatan Tenaga Listrik (TIPTL) pada mata pelajaran Instalasi Motor Listrik.nya dilakukan di kelas XI yang terbagi dalam beberapa kelas, yaitu XI TIPTL 1, XI TIPTL 2, dan XI TIPTL 3. Pembelajaran dilakukan di bengkel Listrik di dalam ruang motor listrik. Pembelajaran Instalasi Motor Listrik untuk XI TIPTL 1 diampu oleh guru B dan sedangkan untuk kelas XI TIPTL 2 dan XI TIPTL 3 diampu oleh, Guru A. Setiap pertemuan terdiri dari 4 jam pelajaran atau sekitar 180 menit, yaitu 45 menit per jam pelajaran dengan jadwal pertemuan sekali setiap, minggu di ruangan yang sama secara bergiliran setiap kelas. Pembelajaran Instalasi Motor Listrik dilaksanakan di ruang Motor yang dilengkapi dengan satu papan tulis white board, satu perlengkapan LCD Proyektor, tiga seperangkat trainer kontrol motor tempat siswa melakukan praktikum Instalasi Motor Listrik, motormotor listrik 3 phasa dan 1 phasa, kabel-kabel konektor, dan alat-alat penunjang praktikum lainnya

Temuan-temuan pada penelitian ini mendeskripsikan model pembelajaran project based learning berbasis kinerja pada mata pelajaran instalasi motor listrik yang meliputi, perencanaan, pelaksanaan, dan evaluasi pembelajaran yang dilakukan oleh guru A dan guru B (guru Instalasi Motor Listrik kelas XI TIPTL ). Bagian ini juga memaparkan temuan-temuan yang telah diperoleh selama penelitian untuk menjawab permasalahan yang diajukan pada bab 1. Data yang dipaparkan berupa deskripsi nyata temuan peneliti terhadap model pembelajaran project based learning berbasis kinerja yang dilakukan guru. Jumlah guru yang diteliti adalah 2 orang guru yang mengajar di kelas XI dan 6 orang siswa kelas XI TIPTL. Data didapat melalui hasil observasi, wawancara, dan kajian dokumen-dokumen yang terkait dengan permasalahan penelitian.

Kinerja guru dalam model pembelajaran project based learning tahap perencanaan, yaitu berdasarkan data yang diperoleh dari guru Insalasi Motor Listrik kelas XI TIPTL SMK Negeri 3 Singaraja, terungkap bahwa perencanaan pembelajaran digunakan sebagai panduan dalam kegiatan pembelajaran agar tidak menyimpang. Perencanaan pembelajaran yang disiapkan berupa Rencana Pelaksanaan Pembelajaran (RPP), jobsheet, media pembelajaran trainer dan perangkat penilaian. Dikarenakan pembelajaran bersifat praktik guru juga mempersiapkan jobsheet untuk dibagikan ke siswa sebagai pedoman praktikum. Guru A dan B menyiapkan perencanaan pembelajaran secara berkelompok. Perencanaan disusun untuk semua kelas XI TIPTL yang 
berjumlah 3 kelas, yaitu XI TIPTL 1, XI TIPTL2 dan XI TIPTL 3. Menurut hasil wawancara dan studi dokumen guru menerapkan Model pembelajaran project based leaning dengan pendekatan saintifik dan metode ceramah, diskusi dan praktek. Guru menggunakan project based learning karena pembelajaran yang bersifat praktik. Guru menyusun jobsheet berpedoman terhadap RPP yang disusun agar sesuai namun, dalam pelaksanaan guru melakukan penyesuaian-penyesuaian dengan kondisi peralatan, waktu yang tersedia dan jumlah siswa. Secara garis besar, susunan RPP guru telah memuat komponen-komponen RPP sebagai berikut: 1) Identitas sekolah, mata pelajaran, kelas/semester, materi pokok, pertemuan, dan alokasi waktu; 2) KI, KD dan indikator pencapaian kompetensi; 3) tujuan pembelajaran; 4) materi pembelajaran dengan memuat fakta, konsep, prinsip, dan prosedur; 5) pendekatan,model dan metode pembelajaran; 6) media, alat dan sumber pembelajaran yang sesuai dengan materi pembelajaran; 7) langkah-langkah pembelajaran yang memuat kegiatan pendahuluan, inti dan penutup; 8) penilaian. Guru juga merancang jobsheet yang memuat komponen-komponen sebagai berikut: 1) identitas jobsheet; 2) tujuan; 3) waktu; 4) gambar

kerja, 5) alat dan bahan; 6) keselamatan kerja; 7) langkah kerja; 8) tugas.

Kinerja guru dalam model pembelajaran project based learning tahap pelaksanaan, yaitu berdasarkan kajian terhadap data observasi dan wawancara dapat dipaparkan bahwa pelaksanaan pembelajaran yang dilakukan oleh guru A dan B meliputi tiga tahap, yaitu pendahuluan, inti, dan penutup. Dalam kegiatan pendahuluan secara keseluruhan hampir sama antara guru $A$ dan $B$, yaitu guru hanya melakukan orientasi saat pendahuluan. Menurut RPP yang disusun, pada kegiatan pendahuluan guru A dan B seharusnya melakukan tiga tahapan, yaitu orientasi, motivasi, dan apersepsi. Guru A dan B masih memiliki kekurangan, yaitu kurang menyiapkan siswa secara psikis dan fisik, kurang memotivasi siswa, kurang menjelaskan dengan tegas tujuan pembelajaran namun tujuan dapat dilihat siswa pada jobsheet yang dibagikan. Dalam kegiatan inti guru A dan B menggunakan model pembelajaran project based learning dengan metode ceramah, diskusi dan praktik dan pendekatan saintifik. Guru A dan B mempersiapkan sumber belajar seperti modul-modul dan memberikan jobsheet yang digunakan siswa sebagai panduan dalam praktikum. Namun jobsheet tercantum gambar kerja rangkaian secara utuh sehingga siswa kurang dilibatkan dalam merencana dan mendesain gambar rangakaian. Media yang direncanakan belum diterapkan secara maksimal. Media utama yang digunakan guru adalah trainer yang dipakai siswa dalam berpraktikum, sedangkan powerpoint yang direncanakan masih tergolong jarang dalamnya, bahkan siswa C,dan D mengaku guru A tidak pernah menggunakan media power point dalam menyampaikan materi. Guru A dan B melakukan pengawasan serta pengamatan kepada siswa saat pratikum. Guru masih memiliki kelemahan dalam memberikan pemahaman kepada siswa dan kurang mengajak siswa dalam merencana sehingga dalamnya banyak siswa yang terlihat kurang bisa membaca gambar kerja yang berimplikasi kepada siswa kurang mengerti dalam menerapkan gambar rangkaian pada trainer. Guru A dan B melakukan penilaian terhadap praktik yang dilakukan, yaitu dengan menggunakan instrument lembar penilaian praktik dimana siswa diamati satu persatu kemudian dinilai pada saat selesai praktik.

Kinerja guru dalam model pembelajaran project based learning tahap evaluasi, yaitu berdasarkan hasil data yang diperoleh dapat dipaparkan bahwa guru dalam evaluasi kurang sesuai dengan Permendikbud nomor 23 tahun 2016, karena evaluasi yang dilakukan belum terlaksana maksimal. Hal ini dikarenakan ketiga aspek penilaian yang meliputi ketiga aspek penilaian tersebut belum semua terlaksana. Pada penilaian sikap guru hanya terlihat menggunakan lembar penilaian praktik yang terdapat aspek disiplin kerja saja. Sedangkan pada aspek penilaian keterampilan guru melakukan penilaian dengan menggunakan lembar penilaian praktikum dan fortofolio yang berupa laporan hasil praktik, namun lembar penilaian praktik tidak dilampirkan pada penilaian keterampilan pada RPP

Perencanaan model pembelajaran project based learning, yaitu Dalam mengajar perencanaan merupakan suatu yang penting dan harus dipersiapkan oleh guru untuk mencapai tujuan pembelajaran. Menurut permendikbud Nomor 22 Tahun 2016 yang menyatakan bahwa perencanaan pembelajaran meliputi penyusunan perencanaan pembelajaran dan penyiapan media dan sumber belajar, perangkat penilaian pembelajaran dan scenario pembelajaran. Selain itu, 
karena merupakan pembelajaran yang berbasis proyek atau project based learning, guru juga harus mempersiapkan perencanaan yang dimana disebutkan oleh Wena (dalam Sutirman,2013:46) persiapan tahap perencanaan pembelajaran proyek meliputi kegiatan merumuskan tujuan proyek; merumuskan strategi pembelajaran; membuat jobsheet; merancang kebutuhan sumber belajar; dan merancang alat evaluasi. Dalam menyusun perencanaan pembelajaran, guru masih memiliki kekurangan diantaranya. Rancangan jobsheet yang kurang merangsang siswa untuk berfikir kritis dalam merancang/mendesain gambar rangkaian Instalasi Motor Listrik dimana gambar tersedia lengkap siswa tinggal mencontoh saja. Hal ini kurang sesuai dengan The George Lucas Educational Foundation yang dikutip Sabar Nurohman (dalam Sutirman, 2013:46) yang menyatakan siswa dengan pendampingan dari guru membuat desain rencana tahapan proyek yang akan dilakukan. Terkait evaluasi yang direncanakan pada RPP meliputi teknik dan bentuk instrument. Evaluasi yang digunakan mengacu pada aspek sikap, aspek pengetahuan, dan aspek keterampilan. Evaluasi pada aspek sikap, yaitu lembar pengamatan sikap dan rubrik serta format jurnal. Namun ada dua aspek yang belum terpenuhi oleh guru, yaitu penilaian diri, dan penilaian teman antar teman sesuai dengan intruksi panduan penilaian Kemendikbud 2016. Evaluasi pada aspek pengetahuan, guru menggunakan tes tertulis yaitu berupa tes esai/ uraian dan penugasan berupa laporan hasil kegiatan sebagai evaluasi pemahaman siswa tentang materi yang telah dibahas hal ini sudah sesuai dengan kompetensi yang dinilai. (Permendikbud Nomor 23 Tahun 2016). Untuk aspek evaluasi keterampilan, guru mencantumkan pada RPP berupa tugas fortofolio, lembar rekapitulasi fortofolio. Seharusnya guru A dan B mencantumkan penilaian praktik pada RPP dimana penilaian tersebut masih terpisah dari RPP.

Pelaksanaan model pembelajaran project based learning, yaitu menurut Permendikbud Nomor 22 Tahun 2016 menyatakan bahwa pelaksanaan pembelajaran merupakan implementasi dari RPP, meliputi kegiatan pendahuluan, inti dan penutup. Menurut hasil telaah pada RPP yang disusun guru A dan B dalam melaksanakan kegiatan pembelajaran membaginya menjadi 3 tahapan, yaitu tahap pendahuluan, kemudian inti dan penutup. Dalam melakukan pembelajaran guru A dan B sedikit kurang taat terhadap RPP yang telah disusun sebelumnya. Pada tahap pendahuluan terdapat 3 tahap kegiatan yang dirancang guru pada RPP, yaitu orientasi, motivasi dan apersepsi. Menurut analisis data siswa dan observasi, guru A dalam melakukan kegiatan pendahuluan sebagian besar hanya melakukan kegiatan orientasi dimana guru A saat masuk kelas memberikan salam kepada siswa serta mengecek kehadiran siswa. Pada tahap desain seharusnya siswa ikut terlibat di dalam mendesain bagaimana rangkaian yang akan dipraktekkan nantinya. Namun jobsheet yang diberikan tercantum gambar rangkaian secara utuh sehingga siswa tidak berfikir kritis di dalam bagaimana rangkaian tersebut bisa tercipta. Seharusnya di dalam jobsheet lebih melibatkan siswa untuk merencanakan gambar rangkaian atau desain rangkaian. Hal ini kurang sesuai dengan The George Lucas Educational Foundation yang dikutip Sabar Nurohman (dalam Sutirman 2013:46) yang menyatakan siswa dengan pendampingan guru membuat desain tahapan rencana proyek yang akan dilakukan. Guru A dalam megakhiri pembelajaran di kelas XI TIPTL3 kurang taat dalam melaksanakan sesuai dengan RPP. Guru A jarang melakukan repleksi atau mengulang kembali tentang apa yang telah dilaksanakan. Hal ini kurang sesuai dengan Permendikbud Nomor 22 Tahun 2016 yang menyatakan dalam kegiatan penutup, guru bersama peserta didik baik secara individual maupun kelompok melakukan refleksi untuk mengevaluasi.

Pelaksanaan model pembelajaran project based learning, yaitu Menurut Permendikbud Nomor 23 tahun 2016 menyebutkan bahwa Penilaian adalah proses pengumpulan dan pengolahan informasi untuk mengukur pencapaian hasil belajar peserta didik. Hal serupa juga disampaikan The George Lucas Educational foundation yang dikutip Sabar Nurohman (dalam Sutirman 2013:46), yaitu penilaian dilakukan untuk mengukur ketercapaian standar, mengevaluasi kemajuan masingmasing siswa, memberi umpan balik tentang tingkat pemahaman yang sudah dicapai, dan menjadi bahan pertimbangan dalam menyusun strategi pembelajaran berikutnya. Guru A dan B dalam menerapkan penilaian kurang sesuai dengan panduan Kemendikbud 2016. Penilaian yang dilakukan guru berupa penilaian sikap, penilaian keterampilan dan penilaian pengetahuan. Dalam penilaian pengetahuan guru menggunakan tes tertulis, yaitu soal pilihan ganda dan tes esay namun dalam RPP tidak tercantum instrumen untuk pilihan ganda. Guru A dan B juga memberikan tugas 
berupa laporan hasil kegiatan. Guru A dan B pada penilaian pengetahuan bisa memilih antara tes lisan dan tes tertulis sesuai dengan intruksi Permendikbud Nomor 22 Tahun 2016 yang menyatakan penilaian aspek pengetahuan dilakukan melalui tes tertulis / tes lisan, dan penugasan sesuai dengan kompetensi yang dinilai. Dalam melakukan praktikum/ keterampilan, Instrumen yang dibawa guru saat mengamati dan menilai siswa praktikum di kelas adalah lembar penilaian praktek. Guru A dan B juga melakukan penilaian fortofolio yang berupa laporan hasil praktek siswa. Menurut intruksi panduan penilaian pada kemendikbud 2016 penilaian yang seharusnya digunakan guru dalam menilai keterampilan meliputi penilaian unjuk kerja / kinerja/ praktik, dan penilaian portofolio. Pada aspek sikap, guru kurang sesuai dengan Kemendikbud 2016. Penilaian yang seharusnya dilakukan guru pada aspek sikap meliputi observasi/pengamatan, penilaian diri, penilaian teman sejawat oleh peserta didik dan jurnal berupa catatan pendidik (Kemendikbud 2016). Guru hanya memnuhi 2 kriteria, yaitu penilaian pengamatan dan jurnal catatan pendidik sedangkan penilaian diri dan penialaian teman sejawat belum terpenuhi.

\section{Kesimpulan dan Saran}

Berdasarkan hasil penelitian dan pembahasan dapat disimpulkan hal-hal sebagai berikut. Secara garis besar, Perencanaan yang dilakukan guru A dan B dalam penerapan model pembelajaran project based learning, yaitu menyusun rencana pelaksanaan pembelajaran (RPP), jobsheet, media dan alat evaluasi sebagai kelengkapan didalam memberikan pengajaran praktikum. RPP yang disusun masih kurang sesuai dengan aspek kinerja guru, karena masih memiliki kelemahan-kelemahan diantaranya: 1) tidak dilengkapi instrument tes pilihan ganda pada aspek pengetahuan; 2) tidak mencantumkan pedoman penilaian diri untuk peserta didik, pedoman penilaian antar teman untuk peserta didik; 3) tidak mencantumkan lembar penilaian praktik pada RPP; 4) jobsheet yang kurang melibatkan siswa dalam mendesain dan merencana gambar rangkaian yang dipraktekkan,

kinerja guru dalam penerapan model pembelajaran project based learning tahap pelaksanaan pembelajaran pada kelas XI TIPTL SMK Negeri 3 Singaraja terdiri dari 3 tahapan, yaitu pendahuluan, kegiatan inti dan penutup. Pada kegiatan pendahuluan guru A dan B hanya melakukan kegiatan orientasi sedangkan motivasi dan apersepsi kurang dilaksanakan. Pada kegiatan inti guru kurang melibatkan siswa dalam kegiatan merencana dan mendesain gambar rangkaian yang dipraktekkan serta kurang mengoptimalkan penggunaan media yang direncanakan. Pada kegiatan penutup guru kurang melakukan kegiatan refleksi dan merangkum bersama siswa dalam menutup pembelajaran, dan

Kinerja guru dalam penerapan model pembelajaran project based learning tahap evaluasi pembelajaran instalasi motor listrik pada kelas XI TIPTL SMK Negeri 3 Singaraja terdiri dari tiga aspek penilaian, yaitu aspek pengetahuan, keterampilan, dan sikap. Evaluasi berjalan belum maksimal karena terdapat item-item yang masih belum terlaksana, yaitu penilaian diri untuk peserta didik, penilaian antar teman untuk peserta didik.

Sesuai dengan temuan dalam penelitian ini, saran yang dapat disampiakan sebagai berikut. 1) guru $A$ dan $B$ diharapkan lebih cermat dalam merancang penilaian. Pada penilaian sikap seharusnya ditambahkan penilaian teman sejawat dan peniliaian diri untuk siswa sesuai Permendikbud 2016. Pada penilaian keterampilan perlu mencantumkan instrument penilaian praktik pada RPP yang disusun sesuai dengan Permendikbud Nomor 22 tahun 2016; 2) guru juga harus memperhatikan merancang jobsheet yang disusun dengan memperhatikan tahapan project based learning sehingga factor desain yang kurang bisa terpenuhi dan siswa ikut terlibat dalam proses desain tersebut sesuai dengan tahapan project based learning; 3) guru A dan B seharusnya melaksanakan apa yang direncanakan pada RPP idealnya pelaksanaan merupakan implementasi dari RPP. Pada tahap pendahuluan seharusnya guru melaksanakan ketiga aspek kegiatan yang telah direncanakan yaitu orientasi motivasi dan apersepsi sesuai dengan RPP tidak hanya pada aspek orientasi saja; 4) kedepannya guru disarankan untuk lebih meninggaktkan lagi kinerja dalam penerapan PJBL sehingga syarat dalam peraturan Kemendikbud yang berlaku dapat terlaksana. 


\section{DAFTAR PUSTAKA}

Arikunto S. \& Safruddin.C.A.J. 2009. Evaluasi Program Pendidikan. Jakarta: PT Bumi Aksara.

Arikunto,S. \& Cepi Safruddin Abdul,J. 2014. Evaluasi Program Pendidikan. Jakarta: Bumi Aksara

Departemen Pendidikan Nasional. 2003. Undang Undang Republik Indonesia Nomor 20 Tahun 2003 tentang Sistem Pendidikan Nasional.

Hamzah \& Lamatenggo. N. 2012. Teori Kinerja dan Pengukurannya. Jakarta: PT Bumi Aksara.

Kementerian Pendidikan dan Kebudayaan. 2016. Peraturan Pemerintah Nomor 23 Tahun 2016 Tentang Standar Penilaian Pendidikan. Tersedia pada: http://bsnp-indonesia.org/wpcontent/uploads/2009/09/Permendikbud_Tahun2016_Nomor023.pdf. Diakses tanggal 07 September 2016.

Sugiyono. 2014. Metode Penelitian Pendidikan (Pendekatan Kuantitatif, Kualitatif, $R$ \& D). Bandung: Alfabeta.

Sutirman. 2013. Media dan Model-Model Pembelajaran Inovatif. Yogyakarata: Graha IImu Tri Agustiana I.G.A. \& Tika I Nyoman. 2013. Konsep Dasar IPA. Yogyakarta: Ombak.

Wibowo. 2012. Manajemen Kinerja. Jakarta : PT Rajagrafindo Persada. 